\title{
Simulation of the Cardiovascular Mechanical System Based on Pressure-Flow Model Rest Condition
}

\author{
Dimas Primasatya, Erry Rimawan, Hendi Herlambang, Horas Canman S \\ Magister Management ${ }^{1}$, Magister Industrial Engineering ${ }^{2,3,4}$ \\ Mercu Buana University, Jakarta State, Indonesia
}

\begin{abstract}
Non-invasive measurement method has made rapid developments in the field of biomedical engineering. One of research is impedance cardiography (ICG), which provide information of pulsation basic. By knowing this kind of measurement technique, it will assist inspection of the patient's physiological condition with cardiovascular system.
\end{abstract}

This research is aimed to determine the mechanical characteristics of the cardiovascular system in the human body such as a wave graph of pressure, flow, and volume, based on pressure-flow model in rest condition, and analyze the simulation results by implementing state of the physiology cardiovascular disease. To obtain the wave chart that is modeled by the cardiovascular system using a lumped parameter method, formulate the differential equations of the pressure-flow dynamics equation for an incompressible fluid in a segment of a cylindrical elastic tube and simulate the model using the Simulink toolboxes from Matlab R2008b.

The simulation with lumped parameter method resulted wave graphics of pressure, flow, and volume of physiological state a person in rest condition, the left ventricular pressure is $120 \mathrm{mmHg}$, right ventricular pressure is $30 \mathrm{mmHg}$, left ventricular outflow is 800 $\mathrm{mL}$ / sec and volume in the left ventricle is $160 \mathrm{~mL}$. By implementing the simulation have been developed on the physiological state of cardiovascular disease, hypertension occurs when the arteries resistance $\mathbf{R 3} i=$ $0.61 \mathrm{mmHg} \times \mathrm{s} \mathrm{mL}$ with the pressure of the left ventricle is $145 \mathrm{mmHg}$. For coronary heart condition, ventricular pressure decreased until $82 \mathrm{mmHg}$ in the value of the coronary arteries resistance is $\mathrm{R30}=\mathbf{0 . 8 5 2}$ $\mathrm{mmHg} \times \mathrm{s} \mathrm{mL}$. This research assumed heart haves the character of passive because there is no feedback signal that can compensate if the pressure in the systemic circulation is reduced.

The research can be concluded that the graph from simulation shows the results are not much different from the reference chart, this results indicates that the equation and the simulation was able to reflect on the human circulatory physiological circumstances. A little different of a graphic simulation result due to differences in the parameters and assumptions used.

Keywords: Cardiovascular Mechanical Systems, Simulation, Pressure, Flow

\section{INTRODUCTION}

Non-invasive measurement method has made rapid developments in the field of biomedical engineering. One of research is impedance cardiography (ICG), which provide information of pulsation basic. By knowing this kind of measurement technique, it will assist inspection of the patient's physiological condition with cardiovascular system ${ }^{1}$.

Knowing the non-invasive measurement techniques will help in examination of the physiological conditions of the patient associated with the system cardiovascular disease or circulatory system that occurs in the body ${ }^{2}$.

The modeling and simulation carried out aim to imitate a variety a model of the human circulatory system. Expected from this modeling can provide data on the different pathological conditions of humans. And calculate the required differential equation. The purpose behind development the model is to get information about physiological phenomena in cycles closed loop-parallel closed cardiovascular system.

In this research, modeling and simulation of the cardiovascular system will built using the simulink toolbox on the Matlab R2008b software. With this modeling and simulation various graph models will be produced representative about blood pressure, blood flow, and the volume of blood flowing at blood vessels. The block diagram in simulink is also useful for visualizing the relationships that occur in the circulatory system (system cardiovascular).

\section{LITERATURE REVIEW}

\section{$>$ Cardiovascular System}

Cardiovascular system is sometimes called bloodvascular or simply referred to as the circulatory system. The cardiovascular system consists of the heart, which is a muscular pumping device, and a closed system of channels

\footnotetext{
${ }^{1}$ F Kappel, "A MATHEMATICAL CARDIOVASCULAR MODEL WITH PULSATILE AND NON-PULSATILE COMPONENTS," 2010.

2 Dyuti Kishorbhai Trivedi, "SIMULATION OF A COMPLETE CARDIOVASCULAR LOOP: DEVELOPMENT OF A SIMULINK BASED PRESSURE-FLOW MODEL TO OBTAIN THE ORIGIN OF THE ELECTRICAL IMPEDANCE CARDIOGRAM" 2009.
} 
called arteries, veins, and capillaries. In the cardiovascular system, blood is pumped by the heart flow around a closed circle or circuit of vessels because through various "circulations" of the body ${ }^{3}$.

The function of circulation is to serve the needs of the network, for transport nutrients to tissues, and to deliver hormones from one part body to other parts of the body. Circulation is divided into systemic circulation and pulmonary circulation. Systemic circulation supplies blood flow to all body tissues except the lungs, therefore this circulation is also called a large circulation or circulation peripheral $^{4}$.

\section{Computational Hemodynamic Model}

A strong analogy between electrical circuits and circulatory fluid systems humans so computing models of the cardiovascular system are easily represented in the form of electrical circuits. Blood vessels can be considered as capacitors with compliance $(\mathrm{C}, \mathrm{mL} / \mathrm{mmHg})$ that the volume of blood $(\mathrm{V}, \mathrm{mL})$, connected to the resistor $(\mathrm{R}, \mathrm{mmHg} \mathrm{s} / \mathrm{mL}$ or PRU) which explains the fluid obstacles faced by flow blood $^{5}$.

\section{- Blood Volume, Blood Flow, Blood Pressure}

For each container, we associate the pressure $\mathrm{P}(\mathrm{t})$ and volume V (t) from blood. Assuming a linear relationship between transmural pressure and total volume, we get

$$
V(t)=c P(t)+V_{u}
$$

Blood flow is described in terms of a mass balance equation, which is level the change in blood volume $\mathrm{V}(\mathrm{t})$ in the compartment is the difference between flow in and out of the compartment. For generic compartments, stated

$$
\frac{d}{d t}(c P(t))=F_{\text {in }}-F_{\text {out }} \text {, }
$$

F flow between two compartments can be explained by Ohm's law. That is, depends on the pressure difference between adjacent compartments and at the resistance $\mathrm{R}$ towards blood flow. Thus will have a relationship

$$
F=\frac{1}{R}\left(P_{1}-P_{2}\right)
$$

Blood pressure is the strength given by blood against unit area of the vessel wall. Because of the pumping action of the heart beating, Arterial pressure varies between systolic pressure $(120 \mathrm{mmHg})$ and diastolic pressure $(80$ $\mathrm{mmHg}$ ) in normal humans ${ }^{6}$.

${ }^{3}$ Rissa Kurnia, "Fakultas kesehatan masyarakat universitas sumatera utara medan 2007," 2009.

4 Guyton Hall, Fisiologi Kedokteran, Third edit (W.B. Saunders Company publication, 1996).

5 Zaid Samar, "Cardiovascular Parameter Estimation using a Computational Model,” 2005.

6 J T Ottesen, M S Olufsen, dan J K Larsen, "Applied Mathematical Models in Human Physiology,” 2006.
- Relationship between Pressure, Flow and Resistance

Flow through vessels can be calculated by the following formula, which is called Ohm's Law:

$$
Q=\frac{\Delta P}{R}
$$

where, $\mathrm{Q}=$ blood flow, $\mathrm{R}=$ resistance, $\Delta \mathrm{P}=$ pressure difference (P1 - P2) between the two ends of blood vessels.

\section{Compressive Fluid-Flow Dynamic Equations}

Pressure-flow dynamics for incompressible fluids in cylinder segments elastic tube can be described by the equation below:

$$
\begin{aligned}
& \checkmark \text { Pressure } \\
& P_{n}=\frac{1}{C_{n}} \int\left(f_{n}-f_{n+1}\right) \cdot d t \\
& \checkmark \text { Flow } \\
& f_{n+1}=\frac{P_{n}-P_{n+1}}{R_{n+1}}
\end{aligned}
$$

\section{Model Parameters Lumped}

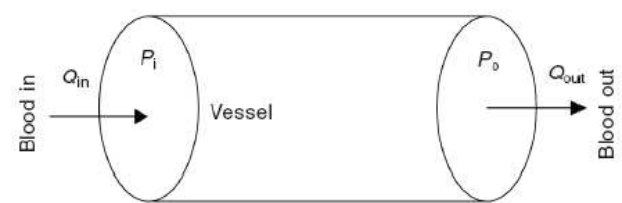

Fig 1:- Elements of Hemodynamics of Blood Vessels

Figure 1 shows part of the hemodynamic elements of blood vessels with blood flow coming in from one end and exiting to the other end is an analogy of hemodynamic $^{2}$ vascular elements.

The same part can be represented as an electric equivalent circuit as shown in Figure 2. In this model, all blood vessels which is represented by the same section. Combining all of these parts, it is possible to get a lumped model of the complete circulation system.

$$
\begin{aligned}
& R: \text { Resistance, } C \text { : Compliance } \\
& L: \text { Inertia } \\
& V_{0}: \text { ZPFV (zero pressure filling volume) }
\end{aligned}
$$

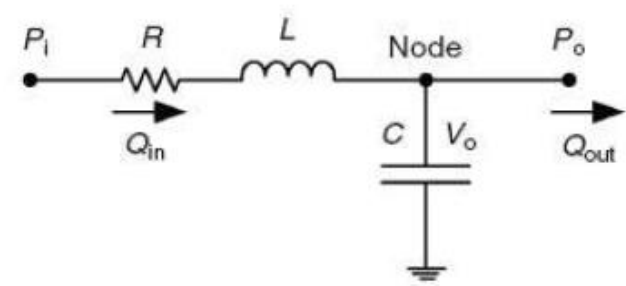

Fig 2:- Representation of Electric Equivalent Circuits ${ }^{7}$

${ }^{7}$ Eun Bo S Him, Jong Youb S Ah, dan Chan Hyun Y Oun, "Mathematical Modeling of Cardiovascular System 


\section{Hypertension and Coronary Heart Disease}

High blood pressure or hypertension, which is an increase abnormal and continuous blood pressure checks are several times caused by one or more risk factors that are not working as it should in maintaining blood pressure normally ${ }^{8}$. As a result of narrowing of arteries found in the left atrium then the resistance will increase so that the pressure on the left ventricle will increase which causes hypertension (high blood pressure). The following pressure criteria Hypertension: systolic pressure (left ventricle) $\geq$ $140 \mathrm{mmHg}$ and diastolic pressure $\geq 90 \mathrm{mmHg}$.

Coronary heart disease is a heart disease caused by coronary artery blockage. Acute blockage occurs because of the presence of atheroxchlerotics coronary artery walls, which block blood flow to the heart muscle tissue ${ }^{9}$. As a result of narrowing of the coronary vessels, the pressure on the ventricles the left will decrease which causes the usual hypotension (low blood pressure) cause weakness or get to death. The following hypotension pressure criteria: systole pressure (left ventricle) $\leq 90 \mathrm{mmHg}$ and diastolic pressure $\leq 60 \mathrm{mmHg}^{10}$.

\section{METHODOLOGY}

\section{Research Methods}

The research method consists of literature study, observation and interaction, guidance. Figure 3 is a research flow chart

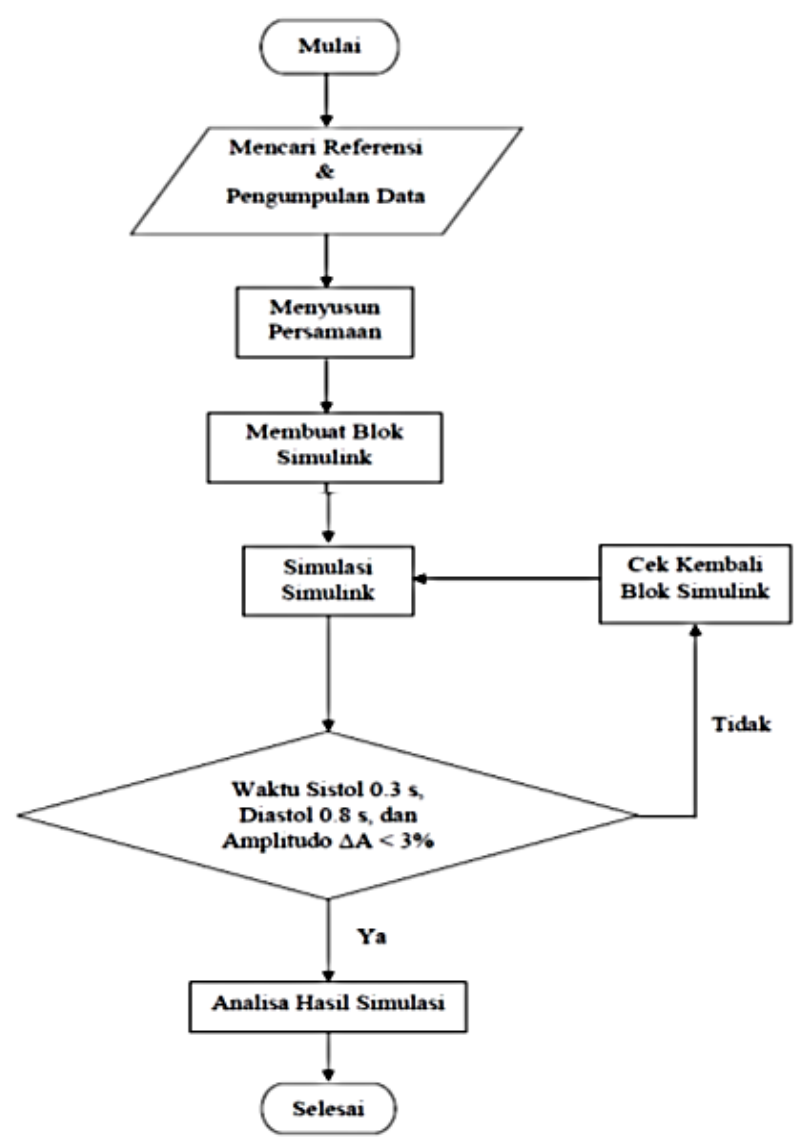

Fig 3:- Research flow chart

\section{Model Assumptions and Parameters}

Here are some of the assumptions in this study because considered in accordance with the reference model, namely:

- The model is intended only to know limited to distribution pressure and flow of the circulatory system (cardiovascular system).

- Blood flow is a flow of Newtonian characteristics in diameter the walls of blood vessels such as arteries and veins are elastic.

- Volume without pressure is zero. Just emphasize volume used in each compartment ie a total of $4600 \mathrm{ml}$.

- Heart rate is set at 75 beats per minute (BPM) with systolic time is 0.3 second and diastolic time 0.5 second.

- "Repeating squence" is used as a capacitance variable to represent variations of systole and diastole in the model.

- This model has no relationship with baroreceptors or with the system central nerve.

- The time span for the simulation is covered by $\mathrm{t}=10-15$ seconds.

- Modeling and simulation using the help of simulink software toolbox Matlab R2008b

Dynamics Using a Lumped Parameter Method" 54, no. 6 (2004): 545-53.

${ }^{8}$ Kurnia, op. cit.

${ }^{9}$ Raden Sanjoyo, "Sistem kardiovaskuler," 2005.

10 S R Pope et al., "Estimation and identification of parameters in a lumped cerebrovascular model," n.d. 
Input and output variables can be seen in the following table:

\begin{tabular}{|c|c|c|c|c|c|}
\hline \multicolumn{5}{|c|}{ Aliran Darahl } \\
\hline Nama & Satuan & Variabel & Nama & Satuan & Variabel \\
\hline tahanana & $\mathrm{mm} H \mathrm{Hg} / \mathrm{m} / \mathrm{sec}$ & $\mathrm{R}$ & radiant area & $\mathrm{mm}^{2}$ & A \\
\hline komplians & $\mathrm{m} / \mathrm{mm} H g$ & $\mathrm{C}$ & berat & gram & W \\
\hline
\end{tabular}

Table 1:- Input Parameters

\begin{tabular}{|c|c|c|}
\hline \multicolumn{3}{|c|}{ Aliran Darah } \\
\hline Nama & Satuan & Variabel \\
\hline tekanan & $\mathrm{mmHg}$ & $\mathrm{P}$ \\
\hline laju alir & $\mathrm{m} / \mathrm{sec}$ & $\mathrm{F}$ \\
\hline volume & $\mathrm{ml}$ & $\mathrm{V}$ \\
\hline
\end{tabular}

Table 2:- Output Parameters

\section{Representation of the Circuit Model}

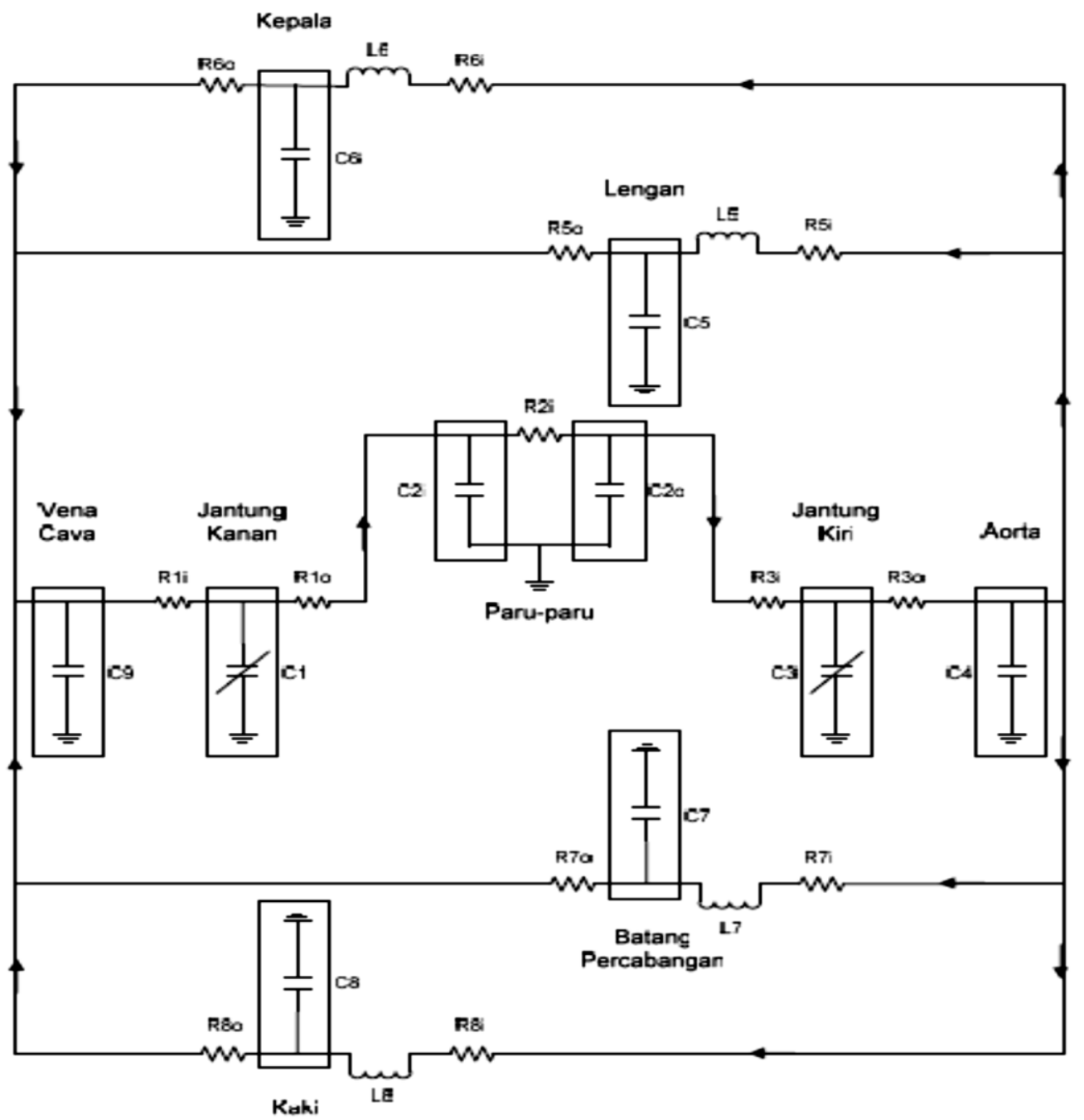

Fig 4:- Lumped Model Simplified Circulation System

\section{Input Function}

These parameters are in Table 3. These parameters are obtained from McLeod research reference, 1966. And can be used to build model in Simulink. Following below are the parameters used in modeling: 


\begin{tabular}{|l|c|c|c|c|c|c|}
\hline & Ri & Ro & C & W & A & Vo \\
\hline Right Heart & 0.0128 & 0.0111 & 75 & 600 & 0 & 150 \\
\hline Lung & 0.1429 & 0 & 7.519 & 1000 & 0 & 120 \\
\hline Left Heart & 0.21 & 0.052 & 80 & 600 & 0 & 150 \\
\hline Aorta & 0 & 0 & 1.25 & 0 & 0 & 100 \\
\hline Arms & 5.15 & 10 & 4.25 & 7000 & 3670 & 280 \\
\hline Head & 2.58 & 5 & 1.21 & 4500 & 1400 & 80 \\
\hline Trunk & 0.67 & 1.42 & 34 & 53000 & 6000 & 2250 \\
\hline Legs & 2.58 & 5 & 11.1 & 18500 & 7000 & 730 \\
\hline Vena Cava & 0 & 0 & 250 & 0 & 0 & 500 \\
\hline Lung2* & 0 & 0 & 30.3 & 0 & 0 & 240 \\
\hline
\end{tabular}

Table 3:- Parameters Used in Modeling ${ }^{11}$

- Input function for right heart (rest condition):

\begin{tabular}{|c|c|c|c|c|c|c|c|c|c|c|c|c|}
\hline Time & 0 & 0.04 & 0.08 & 0.12 & 0.16 & 0.20 & 0.24 & 0.28 & 0.32 & 0.36 & 0.40 & 0.8 \\
\hline $\mathrm{F}(\mathrm{Cr})$ & 0.0033 & 0.05 & 0.10 & 0.15 & 0.17 & 0.24 & 0.30 & 0.36 & 0.40 & 0.30 & 0.0033 & 0.0033 \\
\hline
\end{tabular}

Table 4:- Input function for right heart ${ }^{12}$

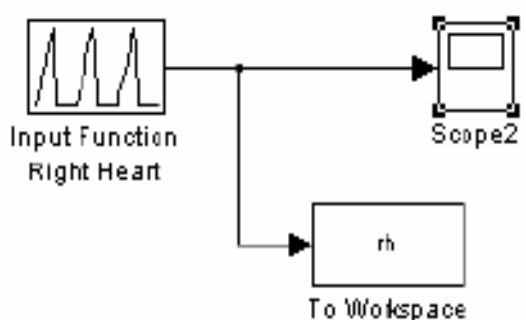

Fig 5:- Simulink Block Representation of the Right Heart Input Function

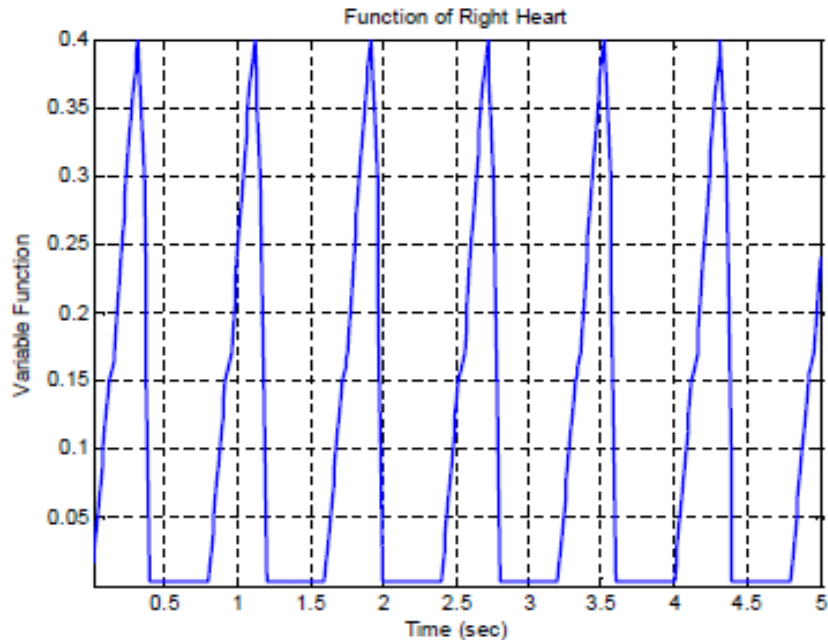

Fig 6:- Input Function of the Right Heart

- Input function for left heart (rest condition):

\begin{tabular}{|c|c|c|c|c|c|c|c|c|c|c|c|c|}
\hline Time & 0 & 0.04 & 0.08 & 0.12 & 0.16 & 0.20 & 0.24 & 0.28 & 0.32 & 0.36 & 0.40 & 0.8 \\
\hline $\mathrm{F}(\mathrm{Cr})$ & 0.0066 & 0.60 & 1.00 & 1.25 & 1.40 & 1.50 & 1.60 & 1.60 & 1.50 & 1.00 & 0.0066 & 0.0066 \\
\hline
\end{tabular}

Table 5:- Input function for left heart ${ }^{13}$

${ }^{11}$ McLeod J, "Physiological simulation benchmark experiment," PHYSBE 7 (1966): 324-29.

12 Ibid.

${ }^{13}$ Ibid. 


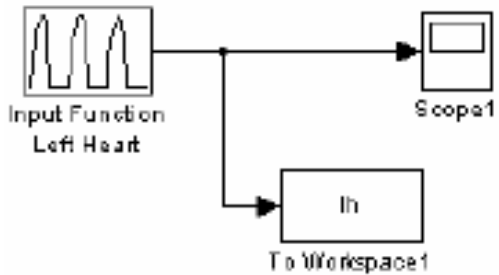

Fig 7:- Simulink Block Representation of the Left Heart Input Function

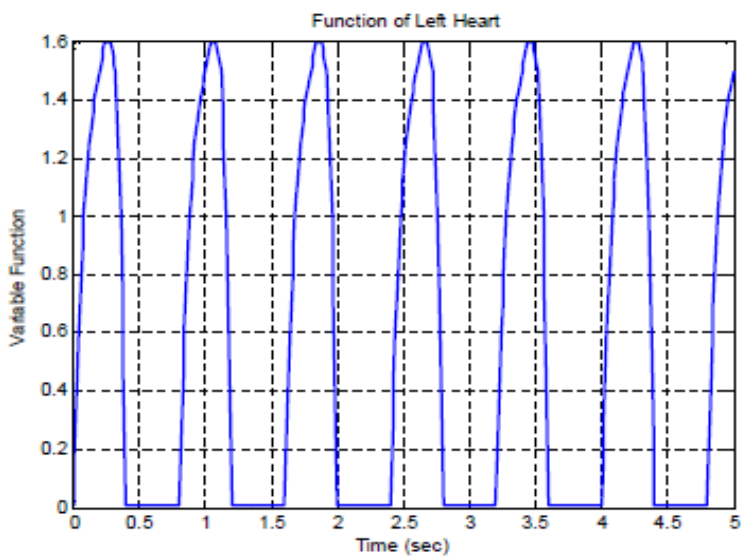

Fig 8:- Input Function of the Left Heart

\section{Representation of the Simulink Model}

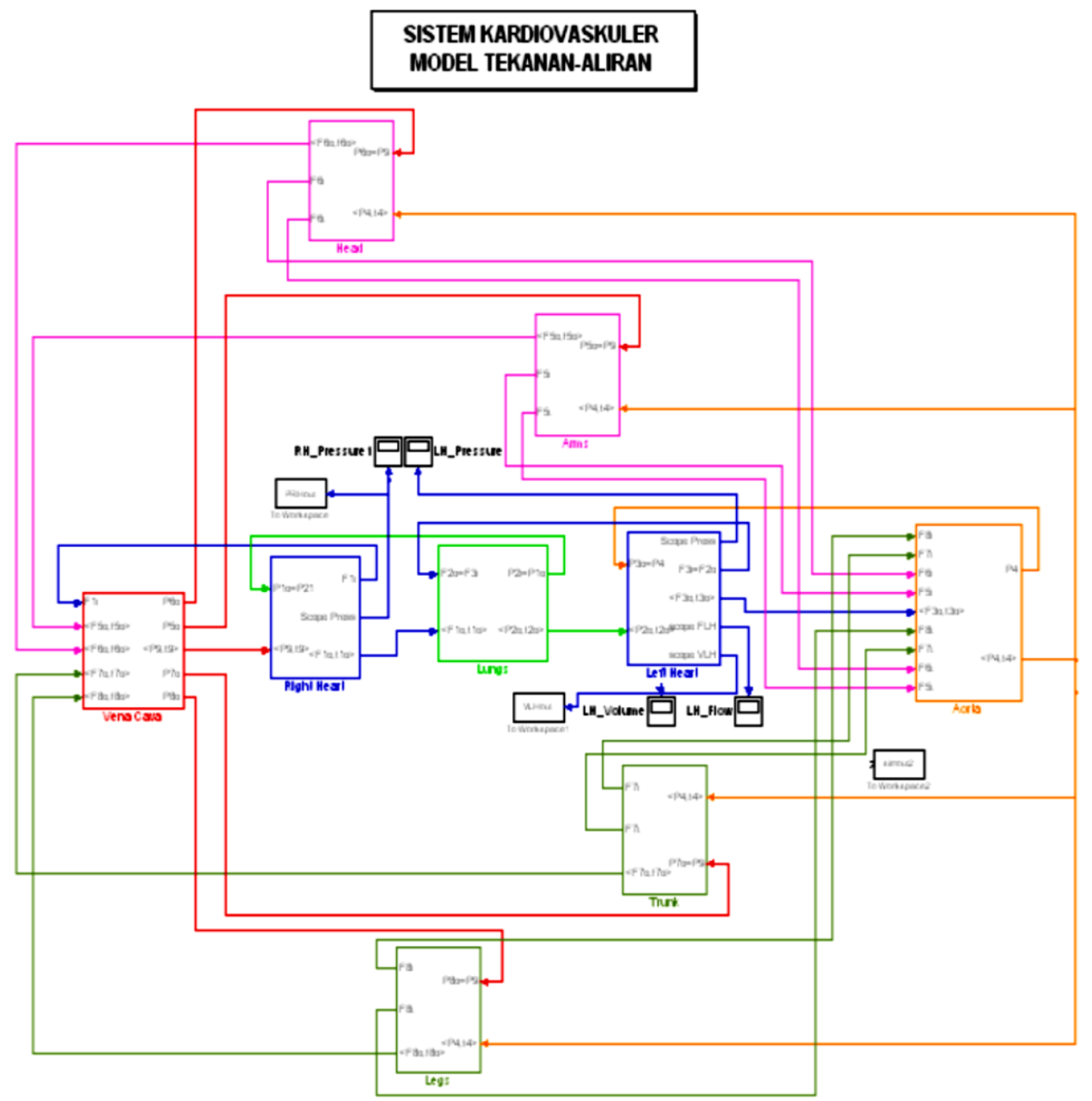

Fig 9:- Simulink Block Representation of the Model

\section{Implementation of Physiological Conditions in the Model}

High blood pressure is established in the model by entering a value resistance / resistance varies in the prisoners who will enter at arteries in the left atrium (R3i) for blood flow between the atria left and left ventricle. Where the value of R3i will be varied from the actual value (at normal conditions). Then the value of the variation will be simulated for prove that with an increase in resistance to the arteries found in the left atrium (R3i) will cause an increase in systolic pressure or on left ventricular pressure out. 
A coronary heart is established in the model by entering values resistance / resistance varies in the prisoners who will come out at coronary arteries found in the left ventricle (R3o) for the intermediate blood flow left ventricle and aorta. Where the value of R3o will be varied from the actual value (at normal conditions). Then the value of the variation will be simulated for prove that with an increase in resistance to the coronary arteries located in the left ventricle (R3o) will cause a decrease in pressure systole or at left ventricular pressure out.

\begin{tabular}{|c|c|c|}
\hline & $\mathrm{R}_{3 \mathrm{i}}(\mathrm{mmHg} \cdot \mathrm{s} / \mathrm{mL})$ & $\mathrm{R}_{30}(\mathrm{mmHg} \cdot \mathrm{s} / \mathrm{mL})$ \\
\hline Normal & 0.21 & 0.052 \\
\hline Variasi 1 & 0.31 & 0.252 \\
\hline Variasi 2 & 0.41 & 0.452 \\
\hline Variasi 3 & 0.51 & 0.652 \\
\hline Variasi 4 & 0.61 & 0.852 \\
\hline
\end{tabular}

Table 6:- Variation in resistance values of R3i arteries and R3o coronary arteries

\section{RESULT}

The output from this simulation model of the blood circulation system is graphical pressure representation both in the right ventricle and in the left ventricle, volume in left ventricle and flow out in the left ventricle in the functioning heart normal that is the number of heart beats 75 beats/minute. Fourth output graph

This is validated by reference charts that have been done before by V. C. Rideout. (Rideout V.C. 1967)

\section{Pressure on the left ventricle (systolic pressure)}

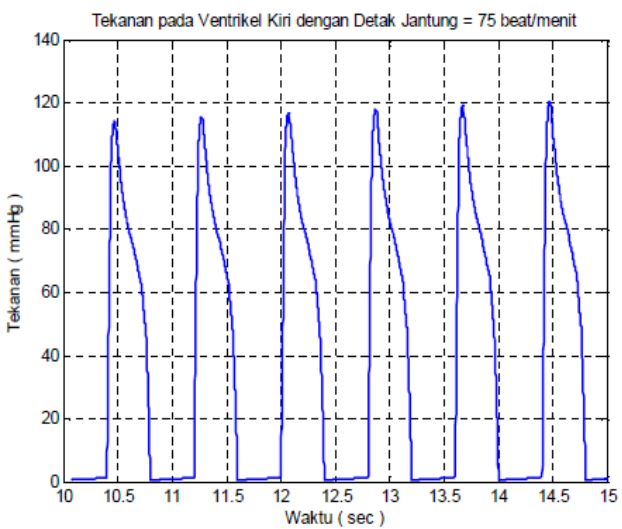

Fig 10:- Pressure Graph on the Left Ventricle Simulation Results in Normal Rest Conditions

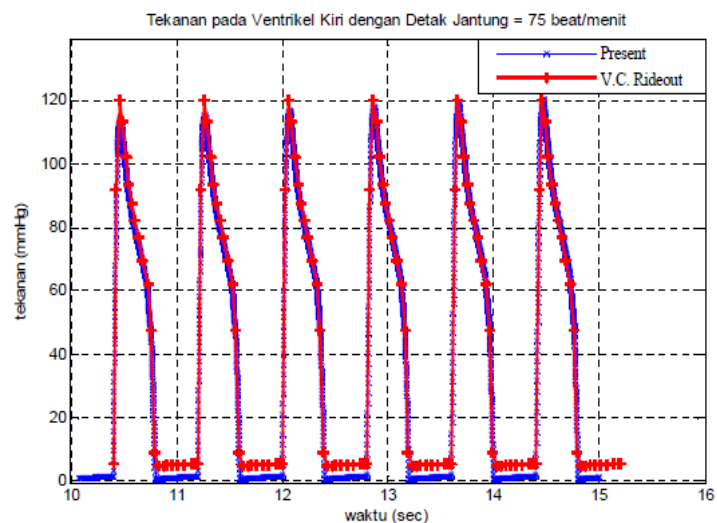

Fig 11:- Validation of Left Ventricular Pressure Graph Simulation Results with Graph Reference

\section{Pressure on the right ventricle}

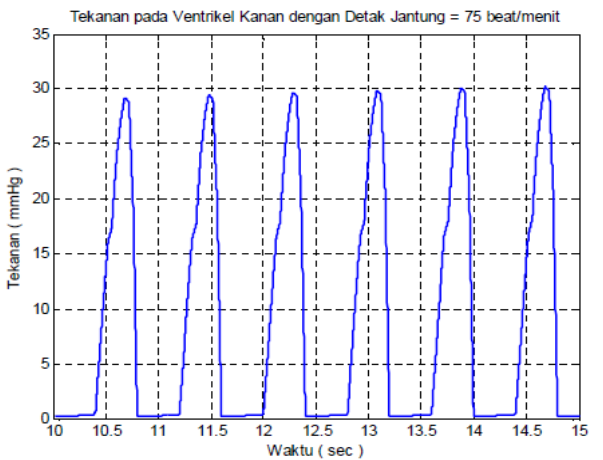

Fig 12:- Pressure graph on the Right Ventricle Simulation Results in Normal Rest Conditions

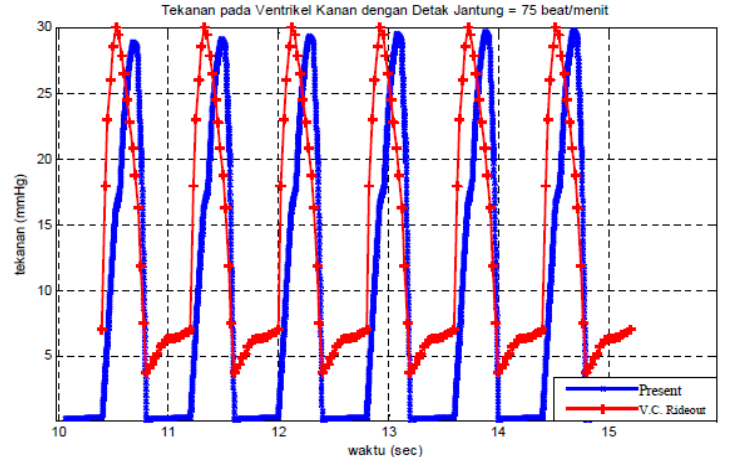

Fig 13:- Validation of Right Ventricular Pressure Graph Simulation Results with Graph Reference 


\section{Outflow in the left ventricle}

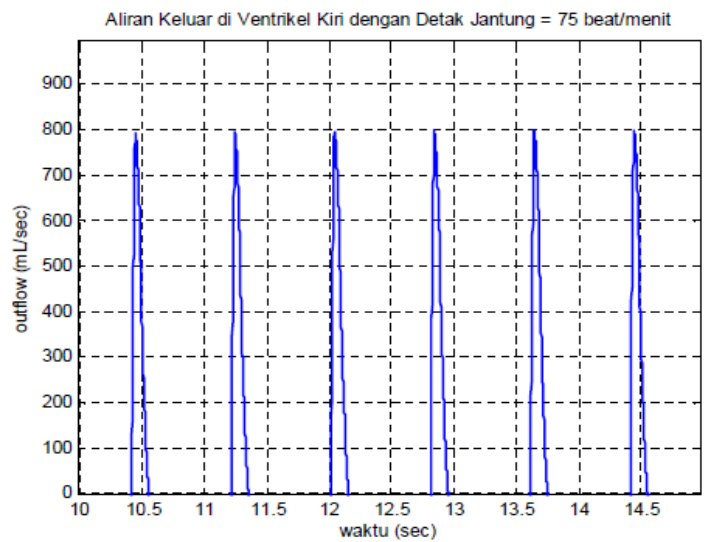

Fig 14:- Outflow Graph on the Left Ventricle Simulation Results in Normal Rest Conditions

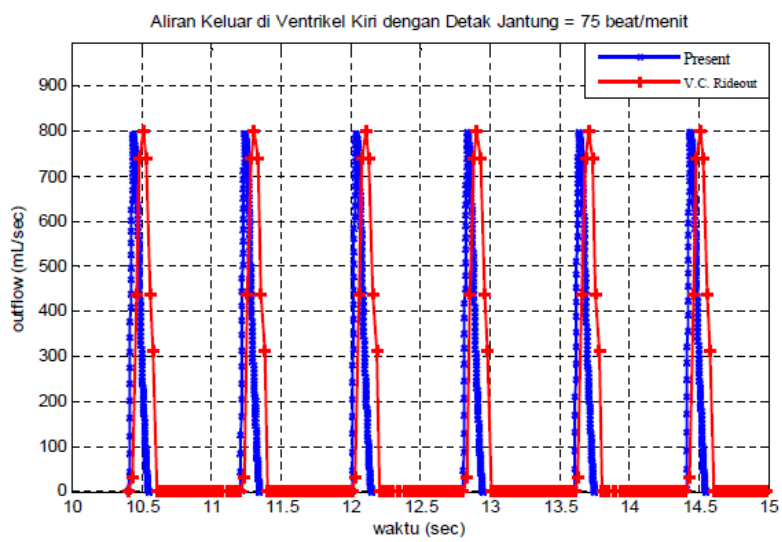

Fig 15:- Validation of Left Ventricular Outflow Graph Simulation Results with Graph Reference

Volume in the left ventricle

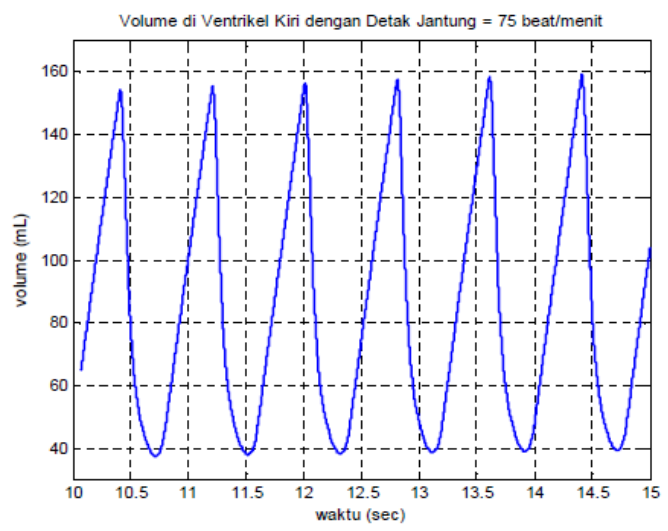

Fig 16:- Volume Graph on the Left Ventricle Simulation Results in Normal Rest Conditions

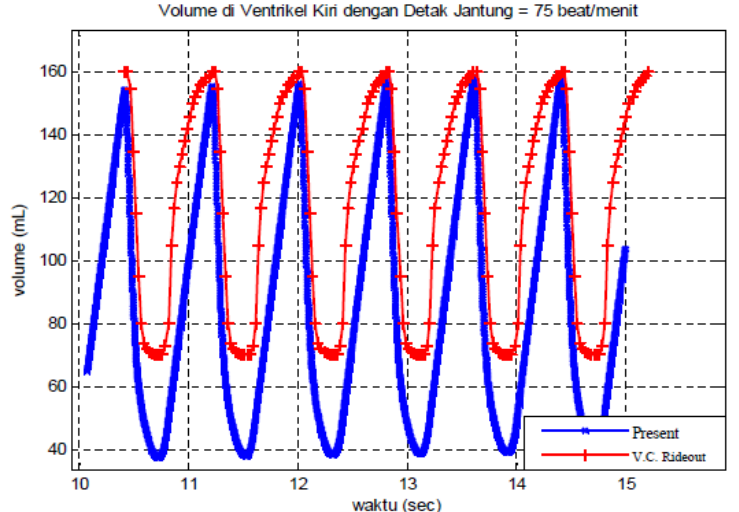

Fig 17:- Validation of Left Ventricular Volume Graph Simulation Results with Graph Reference

Variation in Detention Value and Implementation of Physiological Conditions

- Hypertension

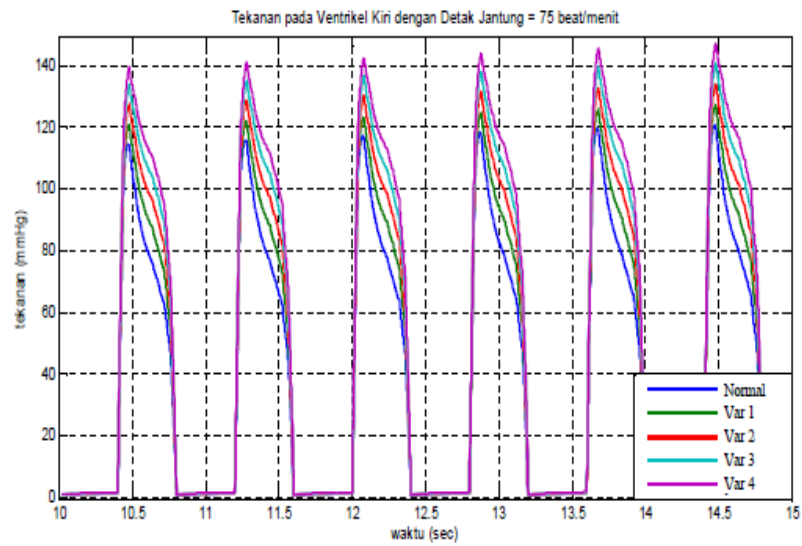

\begin{tabular}{|c|c|c|}
\hline & $R_{3 i}[\mathrm{mmHg} \cdot \mathrm{s} / \mathrm{mL}]$ & Tekanan pada Ventrikel Kiri \\
\hline Normal & 0.21 & $120 \mathrm{mmHg}$ \\
\hline Variasi 1 & 0.31 & $123 \mathrm{mmHg}$ \\
\hline Variasi 2 & 0.41 & $128 \mathrm{mmHg}$ \\
\hline Variasi 3 & 0.51 & $139 \mathrm{mmHg}$ \\
\hline Variasi 4 & 0.61 & $145 \mathrm{mmHg}$ \\
\hline
\end{tabular}

Fig 18:- Left Ventricular Pressure Graph Normal Conditions and Some Variations of R3i 


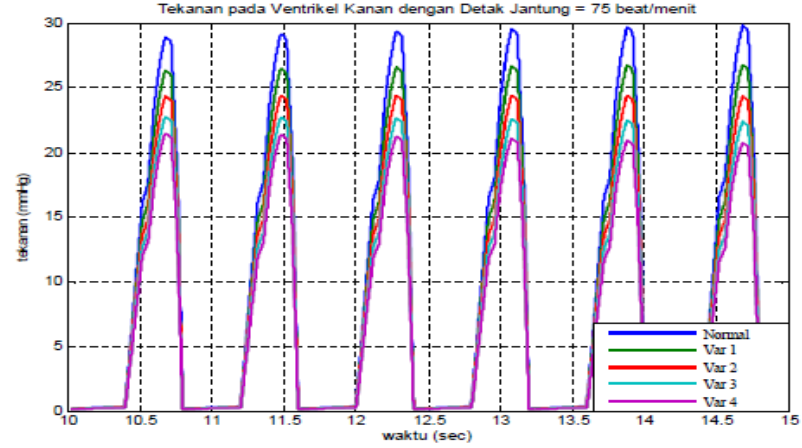

Fig 19:- Normal Ventricular Pressure Graph Normal Conditions and Some Variations of R3i

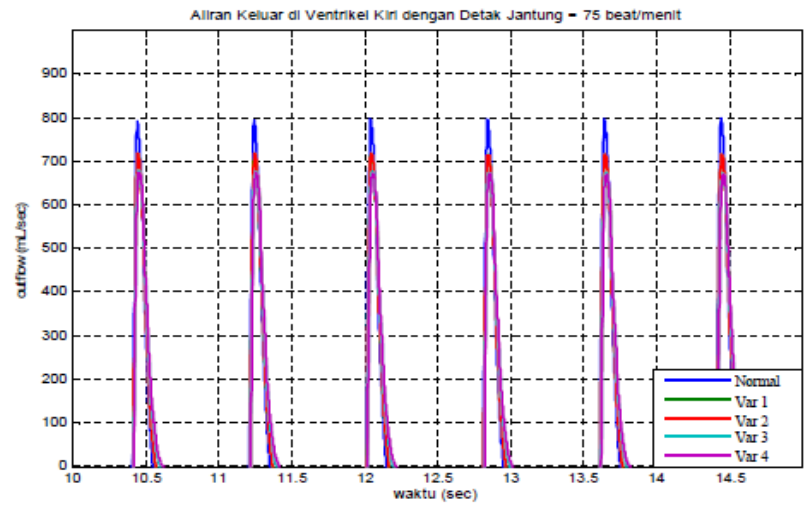

Fig 20:- Normal Left Ventricular Outflow Graph and Some Variations of R3i

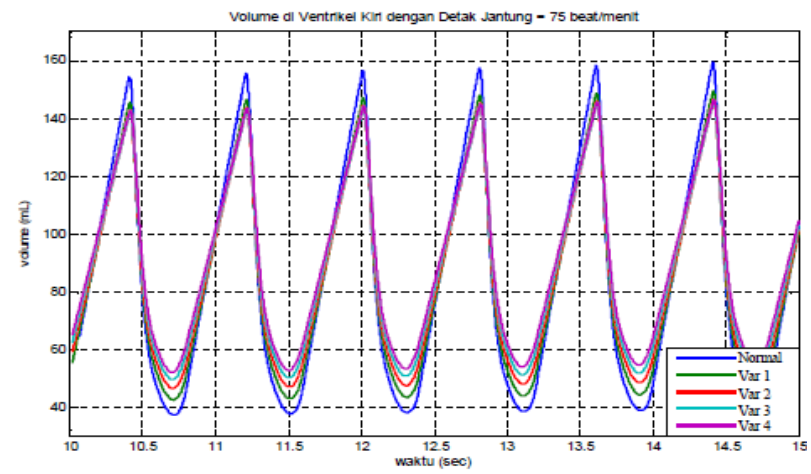

Fig 21:- Normal Left Ventricular Volume Chart and Some Variations of R3i

- Corona heart disease (IMA/Infark Miokard Akut)

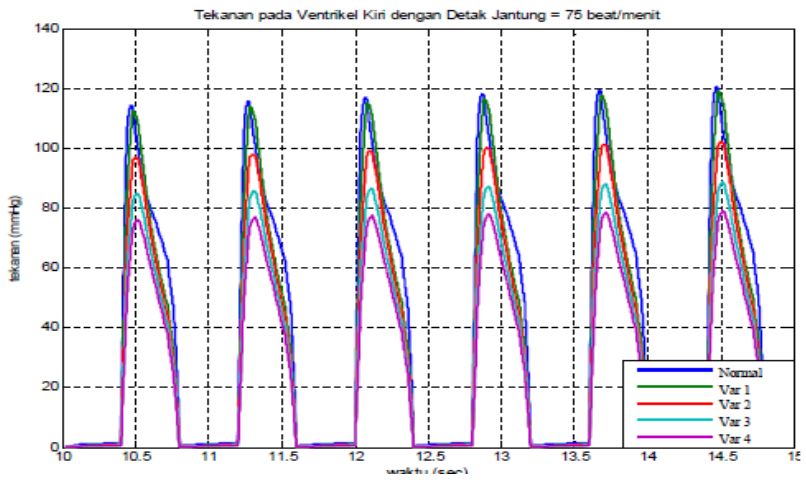

Fig 22:- Left Ventricular Pressure Graph Normal Conditions and Some Variations of R3o

\begin{tabular}{|c|c|c|}
\hline & $\begin{array}{c}\mathrm{R}_{3 \mathrm{i}} \\
{[\mathrm{mmHg} \cdot \mathrm{s} / \mathrm{mL}]}\end{array}$ & $\begin{array}{c}\text { Tekanan Maksimum pada Ventrikel } \\
\text { Kanan }\end{array}$ \\
\hline Normal & 0.21 & $30 \mathrm{mmHg}$ \\
\hline Variasi 1 & 0.31 & $27 \mathrm{mmHg}$ \\
\hline Variasi 2 & 0.41 & $24 \mathrm{mmHg}$ \\
\hline Variasi 3 & 0.51 & $23 \mathrm{mmHg}$ \\
\hline Variasi 4 & 0.61 & $21 \mathrm{mmHg}$ \\
\hline
\end{tabular}

\begin{tabular}{|c|c|c|}
\hline & $R_{3 i}[\mathrm{mmHg} \cdot \mathrm{s} / \mathrm{mL}]$ & Outflow MaksimumVentrikel Kiri \\
\hline Normal & 0.21 & $800 \mathrm{~mL} / \mathrm{sec}$ \\
\hline Variasi 1 & 0.31 & $725 \mathrm{~mL} / \mathrm{sec}$ \\
\hline Variasi 2 & 0.41 & $700 \mathrm{~mL} / \mathrm{sec}$ \\
\hline Variasi 3 & 0.51 & $690 \mathrm{~mL} / \mathrm{sec}$ \\
\hline Variasi 4 & 0.61 & $680 \mathrm{~mL} / \mathrm{sec}$ \\
\hline
\end{tabular}

\begin{tabular}{|c|c|c|c|}
\hline & $\mathrm{R}_{3 \mathrm{i}}$ & \multicolumn{2}{|c|}{ Volume Ventrikel Kiri } \\
\cline { 3 - 4 } & {$[\mathrm{mmHg} \cdot \mathrm{s} / \mathrm{mL}]$} & Batas Atas & Batas Bawah \\
\hline Normal & 0.21 & $160 \mathrm{~mL}$ & $40 \mathrm{~mL}$ \\
\hline Variasi 1 & 0.31 & $148 \mathrm{~mL}$ & $45 \mathrm{~mL}$ \\
\hline Variasi 2 & 0.41 & $142 \mathrm{~mL}$ & $50 \mathrm{~mL}$ \\
\hline Variasi 3 & 0.51 & $142 \mathrm{~mL}$ & $53 \mathrm{~mL}$ \\
\hline Variasi 4 & 0.61 & $143 \mathrm{~mL}$ & $55 \mathrm{~mL}$ \\
\hline
\end{tabular}

\begin{tabular}{|c|c|c|}
\hline & $\mathrm{R}_{30}[\mathrm{mmHg} \cdot \mathrm{s} / \mathrm{mL}]$ & Tekanan pada Ventrikel Kiri \\
\hline Normal & 0.052 & $120 \mathrm{mmHg}$ \\
\hline Variasi 1 & 0.252 & $117 \mathrm{mmHg}$ \\
\hline Variasi 2 & 0.452 & $100 \mathrm{mmHg}$ \\
\hline Variasi 3 & 0.652 & $90 \mathrm{mmHg}$ \\
\hline Variasi 4 & 0.852 & $82 \mathrm{mmHg}$ \\
\hline
\end{tabular}




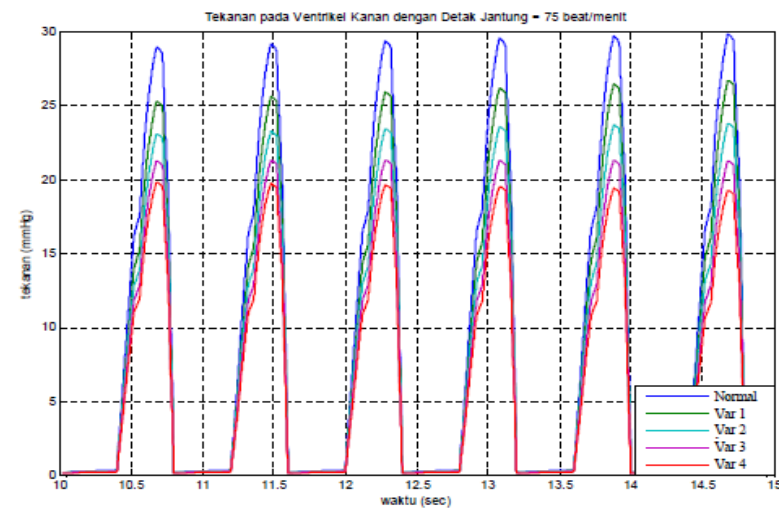

Fig 23:- Normal Ventricular Pressure Graph Normal Conditions and Some Variations of R3o

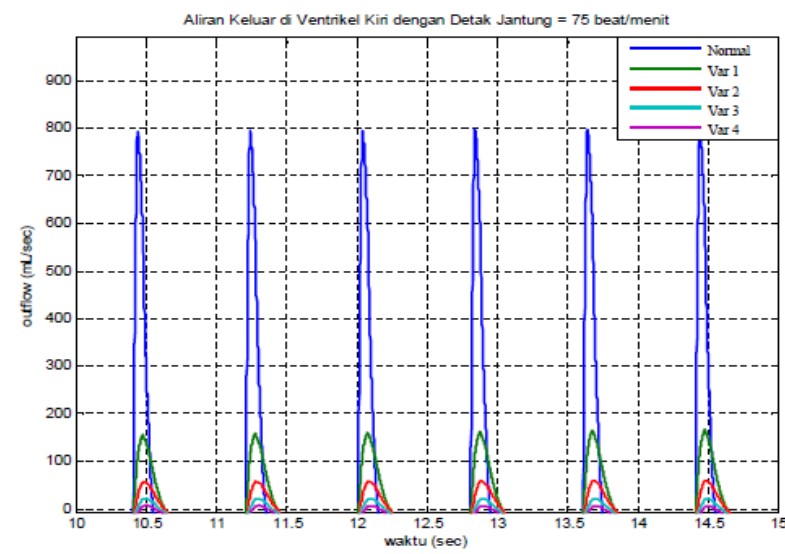

Fig 24:- Normal Left Ventricular Outflow Graph and Some Variations of R3o

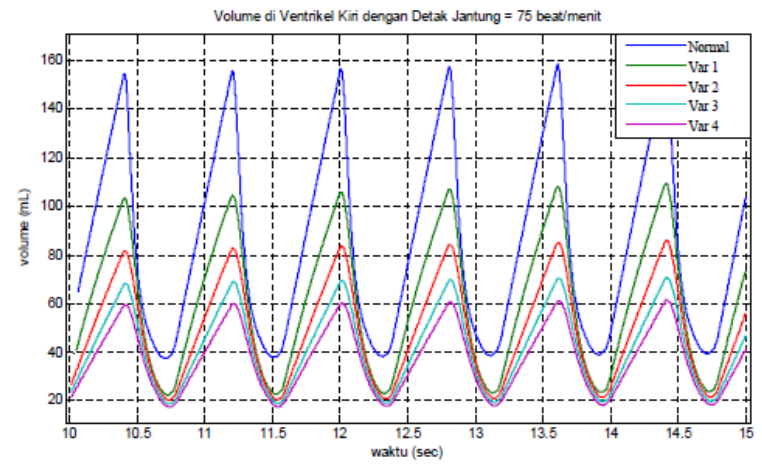

Fig 25:- Normal Left Ventricular Volume Chart and Some Variations of R3o

\begin{tabular}{|c|c|c|}
\hline & $\mathrm{R}_{30}[\mathrm{mmHg} \cdot \mathrm{s} / \mathrm{mL}]$ & Tekanan pada Ventrikel Kanan \\
\hline Normal & 0.052 & $30 \mathrm{mmHg}$ \\
\hline Variasi 1 & 0.252 & $21 \mathrm{mmHg}$ \\
\hline Variasi 2 & 0.452 & $16.5 \mathrm{mmHg}$ \\
\hline Variasi 3 & 0.652 & $14.5 \mathrm{mmHg}$ \\
\hline Variasi 4 & 0.852 & $17 \mathrm{mmHg}$ \\
\hline
\end{tabular}

\begin{tabular}{|c|c|c|}
\hline & $\mathrm{R}_{30}[\mathrm{mmHg} \cdot \mathrm{s} / \mathrm{mL}]$ & Oufflow MaksimumVentrikel Kiri \\
\hline Normal & 0.052 & $800 \mathrm{~mL} / \mathrm{sec}$ \\
\hline Variasi 1 & 0.252 & $160 \mathrm{~mL} / \mathrm{sec}$ \\
\hline Variasi 2 & 0.452 & $60 \mathrm{~mL} / \mathrm{sec}$ \\
\hline Variasi 3 & 0.652 & $23 \mathrm{~mL} / \mathrm{sec}$ \\
\hline Variasi 4 & 0.852 & $7 \mathrm{~mL} / \mathrm{sec}$ \\
\hline
\end{tabular}

\begin{tabular}{|c|c|c|c|}
\hline & \multirow{2}{*}{$\begin{array}{c}\mathrm{R}_{30} \\
{[\mathrm{mmHg} \cdot \mathrm{s} / \mathrm{mL}]}\end{array}$} & \multicolumn{2}{|c|}{ Volume Ventrikel Kiri } \\
\cline { 3 - 4 } & 0.052 & $160 \mathrm{~mL}$ & $40 \mathrm{~mL}$ \\
\hline Normal & 0.252 & $70 \mathrm{~mL}$ & $23 \mathrm{~mL}$ \\
\hline Variasi 1 & 0.452 & $50 \mathrm{~mL}$ & $18 \mathrm{~mL}$ \\
\hline Variasi 2 & $42 \mathrm{~mL}$ & $15 \mathrm{~mL}$ \\
\hline Variasi 3 & 0.652 & 42 & Batas Bawah \\
\hline Variasi 4 & 0.852 & $40 \mathrm{~mL}$ & $15 \mathrm{~mL}$ \\
\hline
\end{tabular}


- Relationship of Arterial Prisoners (R3i) with Hypertension

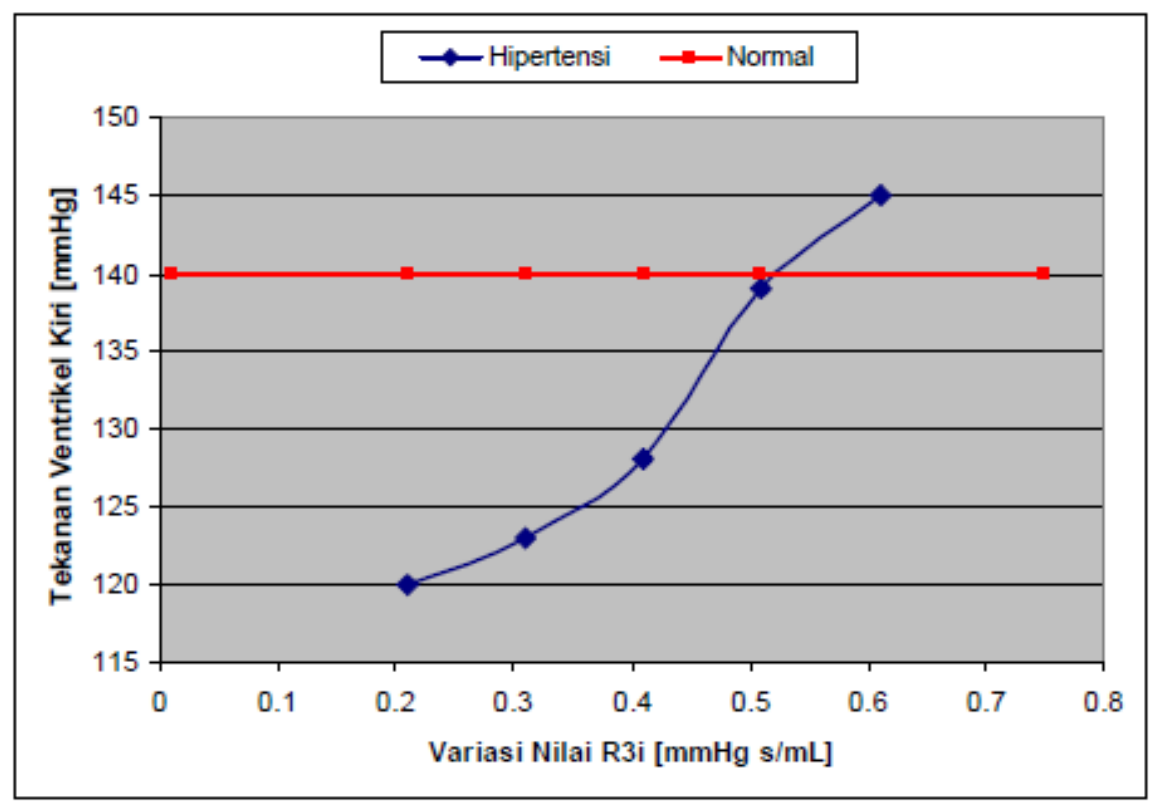

Fig 26:- Graph of Relationship of Arterial Resistance (R3i) with Pressure Left ventricle

- Relationship of Coronary Artery Prisoners (R3o) with Disease Coronary heart

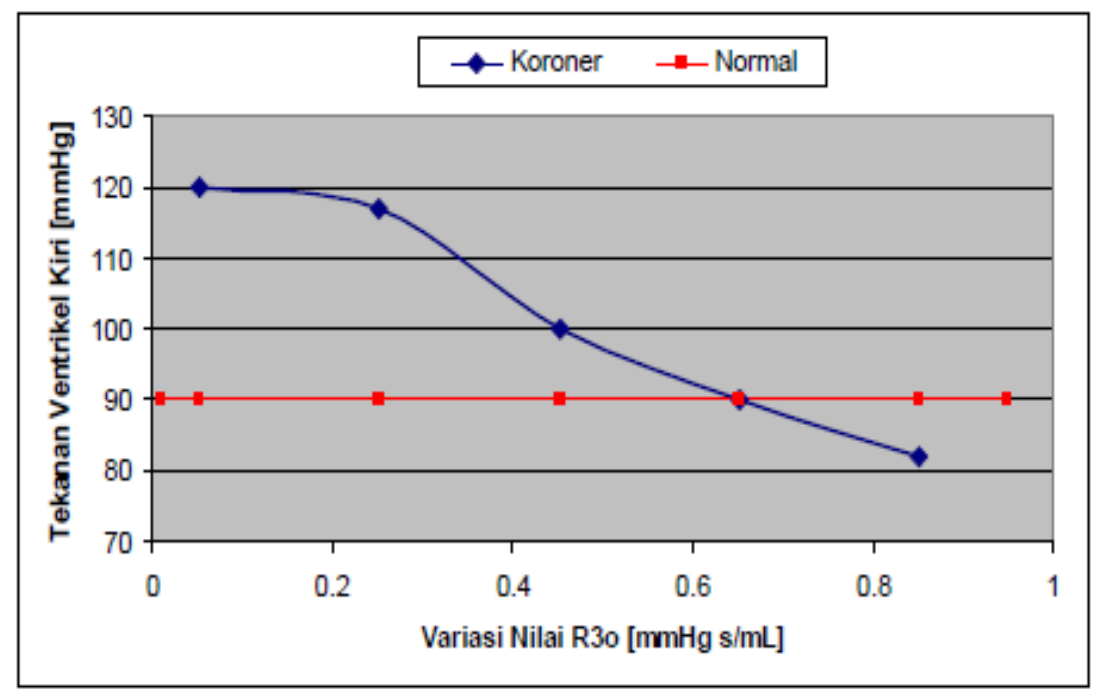

Fig 27:- Graph of Relationship of Artery Coronary Resistance (R3i) with Pressure Left ventricle

\section{CONCLUSIONS}

Characteristics of cardiovascular mechanical systems in human body conditions breaks can be known by modeling and simulating the system blood circulation by using the lumped parameter model which is represented in the form of pressure, flow and volume graphs, where the simulation results are:

$>$ Left ventricular pressure (systolic pressure) is 120 $\mathrm{mmHg}$

Right ventricular pressure is $30 \mathrm{mmHg}$

$>$ The maximum outflow in the left ventricle is $800 \mathrm{~mL} /$ sec

The maximum volume in the left ventricle is $160 \mathrm{~mL}$
High blood pressure or hypertension occurs due to increased resistance in the arteries (R3i), where the greater the resistance value then the greater the pressure on the left ventricle which occurs in the 4 th variation where $\mathrm{R} 3 \mathrm{i}=$ $0.61 \mathrm{mmHg} \times \mathrm{s} \mathrm{mL}$ with a value of left ventricular pressure (pressure systole) reaches $145 \mathrm{mmHg}$.

Coronary heart disease (IMA) occurs due to increased resistance to the vessels coronary artery (R3o), where the greater the resistance value the pressure in the left ventricle is decreasing, which occurs in the 4 th variation with $\mathrm{R} 3 \mathrm{i}=$ $0.852 \mathrm{mmHg} \times \mathrm{s} \mathrm{mL}$ with left ventricular pressure value (systole pressure) reach $82 \mathrm{mmHg}$. 


\section{REFERENCES}

[1]. Hall, Guyton. Fisiologi Kedokteran. Third edit. W.B. Saunders Company publication, 1996.

[2]. Him, Eun Bo S, Jong Youb S Ah, dan Chan Hyun Y Oun. "Mathematical Modeling of Cardiovascular System Dynamics Using a Lumped Parameter Method" 54, no. 6 (2004): 545-53.

[3]. Kappel, F. "A MATHEMATICAL CARDIOVASCULAR MODEL WITH PULSATILE AND NON-PULSATILE COMPONENTS," 2010.

[4]. Kurnia, Rissa. "Fakultas kesehatan masyarakat universitas sumatera utara medan 2007,” 2009.

[5]. McLeod J. "Physiological simulation benchmark experiment." PHYSBE 7 (1966): 324-29.

[6]. Ottesen, J T, M S Olufsen, dan J K Larsen. "Applied Mathematical Models in Human Physiology," 2006.

[7]. Pope, S R, L M Ellwein, C L Zapata, V Novak, C T Kelley, dan $\mathrm{M} S$ Olufsen. "Estimation and identification of parameters in a lumped cerebrovascular model," n.d.

[8]. Samar, Zaid. "Cardiovascular Parameter Estimation using a Computational Model," 2005.

[9]. Sanjoyo, Raden. "Sistem kardiovaskuler," 2005.

[10]. Trivedi, Dyuti Kishorbhai. "SIMULATION OF A COMPLETE CARDIOVASCULAR LOOP: DEVELOPMENT OF A SIMULINK BASED PRESSURE-FLOW MODEL TO OBTAIN THE ORIGIN OF THE ELECTRICAL IMPEDANCE CARDIOGRAM," 2009. 